\title{
Contributions to the
}

Geology of Uranium

1958

GE OLOGICAL SUR VEY B U L L E T I N 1087

This bulletin was printed as separate chapters $A-J$

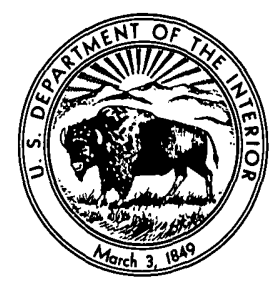


UNITED STATES DEPARTMENT OF THE INTERIOR

STEWART L. UDALL, Secretary

GEOLOGICAL SURVEY

Thomas B. Nolan, Director 


\section{CONTENTS}

[The letters in parentheses preceding the titles designate separately published reports]

(A) Geology of the Garo uranium-vanadium-copper deposit, Park County, Colo., by Verl R. Wilmarth

(B) Uranium resources of the Cedar Mountain area, Emery County, Utah, by Henry S. Johnson, Jr.--.--

(C) Uranium resources of the Green River and Henry Mountain districts, Utah-a regional synthesis, by Henry S. Johnson, Jr.......-.-.-

(D) Geology and uranium deposits of Monument Valley, San Juan County, Utah, by Richard Q. Lewis, Sr., and Donald E. Trimble_.........-

Page

(E) Stratigraphy and uranium content of the Chattanooga shale in northeastern Alabama, northwestern Georgia, and eastern Tennessee, by Lynn Glover.

(F) Geology and ore deposits of the Kern River uranium area, California, by E. M. MacKevett, Jr

(G) Uranium content of ground and surface waters in a part of the central Great Plains, by E. R. Landis

(H) Geology of the Clay Hills area, San Juan County, Utah, by Thomas E. Mullens

(I) Relation of uranium deposits to tectonic pattern of the central Cordilleran foreland by Frank W. Osterwald and Basil G. Dean.--

(J) Geology of the Lost Creek schroeckingerite deposits, Sweetwater County, Wyo., by Douglas M. Sheridan, Charles H. Maxwell, and John T. Collier. 


\section{Geology of the Garo}

\section{Uranium-Vanadium}

Copper Deposit

Park County, Colorado

By VERL R. WILMARTH

CONTRIBUTIONS TO THE GEOLOGY OF URANIUM

GE OLOG I C A S U R V E Y B U L L E T I N 1087-A

This report concerns work done on behalf of the U.S. Atomic Energy Commission and is published with the permission of the Commission

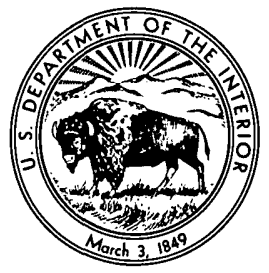




\title{
UNITED STATES DEPARTMENT OF THE INTERIOR
}

\author{
FRED A. SEATON, Secretary
}

\section{GEOLOGICAL SURVEY}

Thomas B. Nolan, Director

For sale by the Superintendent of Documents, U.S. Government Printing Office Washington 25, D.C. 


\section{CONTENTS}

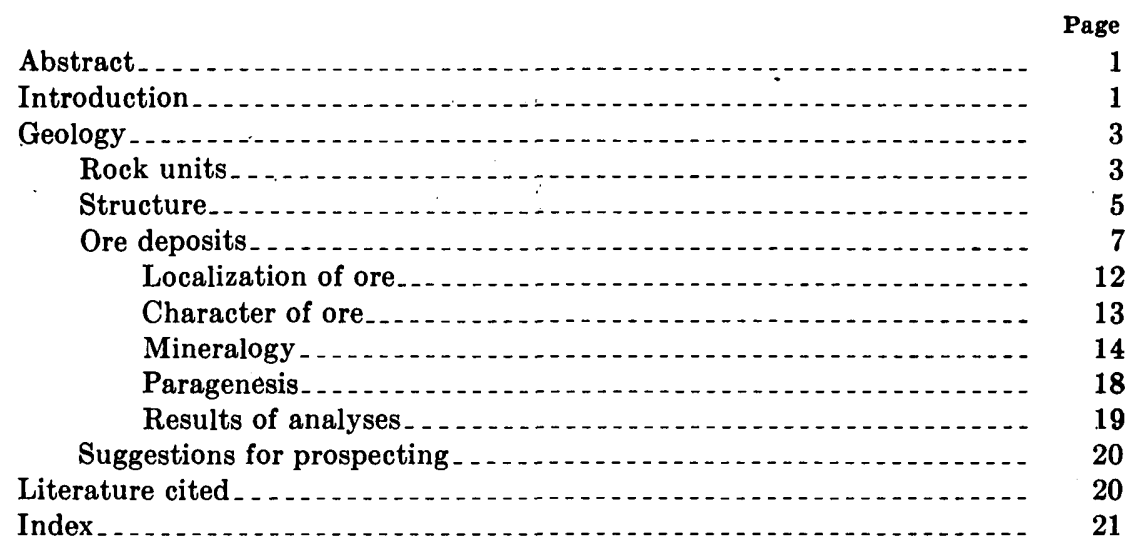

\section{ILLUSTRATIONS}

[Plates 1-5 in pocket]

Plate 1. Geologic map of the Garo deposit.

2. Geologic map of pits 1-3.

3. Isometric diagram showing relation of faults to the ore-bearing sandstone beds.

4. Sections through diamond-drill holes 1-12.

5. Sketch of polished hand specimens showing mineral relations.

Figure 1. Index map of Colorado showing location of Garo deposit

2. Tectonic map of South Park 6

\section{TABLES}

TABLE 1. Sample and assay data for Garo deposit

2. Semiquantitative spectrographic analyses 



\title{
CONTRIBUTIONS TO THE GEOLOGY OF URANIUM
}

\section{GEOLOGY OF THE GARO URANIUM-VANADIUM-COPPER DEPOSITS, PARK COUNTY, COLORADO}

\author{
By Verl R. Wilmarth
}

\begin{abstract}
The Garo deposit, near Garo in the west-central part of Park County, Colo., was mined for radium in 1919 and for uranium, vanadium, and copper in 1951 and 1952.

The ore minerals that constitute the deposit are in three complexly faulted sandstone beds of the Maroon formation of Pennsylvanian and Permian age, on the northeast flank of the northwest-trending Garo anticline. Most of the ore that has been mined came from the youngest sandstone bed (bed 1), but some ore has been produced from the oldest sandstone bed (bed 3). The ore bodies are small and lenticular and apparently are confined to the more permeable parts of the sandstone beds adjacent to minor subsidiary faults. Sedimentary structures may have aided in localizing the ore bodies.

Channel samples from the ore bodies in bed 1 contain as much as 0.48 percent uranium and 1.37 percent $\mathrm{V}_{2} \mathrm{O}_{5}$, whereas samples from sandstone bed 3 contains as much as 0.062 percent uranium and 0.49 percent $\mathrm{V}_{2} \mathrm{O}_{5}$. Copper has been produced from sandstone bed 1.

Within the ore bodies the ore minerals-tyuyamunite, metatyuyamunite, volborthite, carnotite, covellite, chalcocite, azurite, and malachite-occur in fissure veins and as disseminated grains between the detrital grains in the sandstone. The dominant gangue minerals are calcite, hematite, and chalcedony. The original minerals-chalcocite, covellite, pyrite, and possibly uraninite and montroseite-have been oxidized and only small remnants of the primary sulfide minerals were observed in the ore. Oxidation of the primary uranium and vanadium minerals resulted in the formation of tyuyamunite, metatyuyamunite, volborthite, and carnotite and small quantities of uranophane and calciovolborthite.

The intersection of faults which cut the rocks of the Maroon formation should be used as a guide in prospecting for uranium in the vicinity of Garo.
\end{abstract}

\section{INTRODUCTION}

The Garo deposit, known also as the Shirley May mine, is about 1 mile south of Garo, Park County, Colo., and about 11 miles southeast of Fairplay, the nearest supply center (fig. 1). The mine is at an 


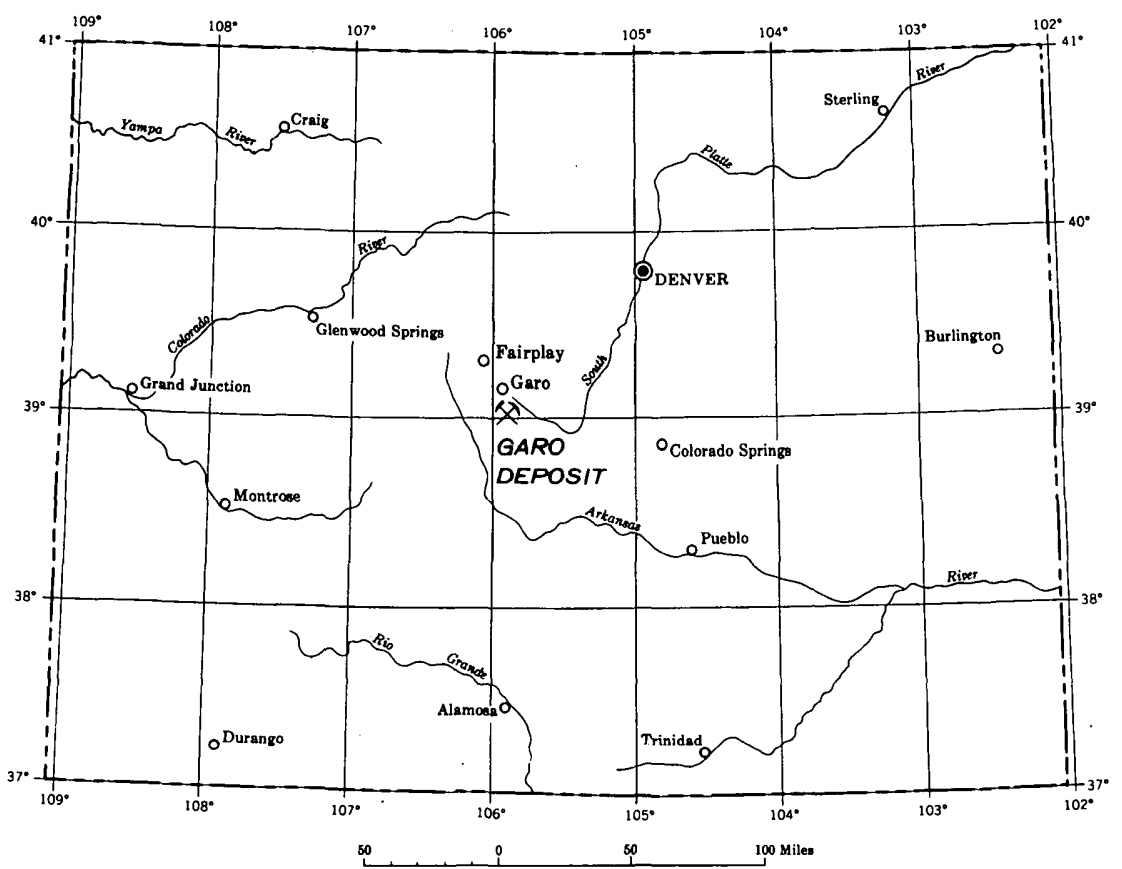

Figure 1.-Index map of Colorado showing location of Garo deposit.

elevation of about 9,000 feet in the central part of South Park, a broad flat valley between the Front Range on the east and the Mosquito Range on the west. The winters are long and snowfall generally heavy ; mining operations, therefore, are limited to the summer months. Water for mining and domestic needs can be obtained from the Middle Fork of the South Platte River, 2 miles north of the mine.

According to Fleck (1909, p. 35), the Garo deposit was first prospected in 1903, but no ore was produced. In 1917, the deposit was again prospected, and in 1919 about 40 tons of ore containing as much as 1 percent uranium was mined (L. B. Riley, 1946, written communication). The mine was idle from 1919 until 1951, when W.H. Gaddis of Hartsel, Colo., commenced open-pit mining and rehabilitated some of the underground workings. Between July 1, 1951, and July 15,1952 , when mining was again discontinued, ore containing uranium, vanadium, and copper was mined from the open pits.

The Garo deposit was first described by Fleck (1909) who identified volborthite as the principal ore mineral in samples containing as much as 5.5 percent copper and 0.55 percent $\mathrm{V}_{2} \mathrm{O}_{5}$. G. B. Guilotte (1944, written communication) briefly described the deposit, and L. B. Riley (1946, written communication) identified carnotite, volborthite, calciovolborthite, malachite, and azurite in specimens of the dump material. According to Stark and others (1949, p. 46), minor quantities of copper-vanadium minerals occur in carbonaceous-rich sand- 
stone of the Maroon formation of Pennsylvanian and Permian age near Garo; near Twin Bridges, about 8 miles southwest of Garo, similar sandstones of the Maroon formation contain copper minerals. The Garo deposit was examined briefly and sampled in 1950 by T. P. Anderson (1950, written communication), and in 1951 by R. U. King (1951, written communication). The first detailed geologic investigation of the ore deposit was made by G. B. Gott (1951, written communication), who mapped on a large scale a small area surrounding the deposit.

During June 1952, V. R. Wilmarth and L. R. Page, of the Geological Survey, and L. E. Smith, of the Atomic Energy Commission, mapped the geology and topography of an area, about one-half square mile, surrounding the deposit. This work was undertaken to obtain information on the structure, mode of occurrence, and extent of the ore-bearing formations and to prepare a base map for use in a diamond-drilling exploration program. The work was done on behalf of the Division of Raw Materials of the U.S. Atomic Energy Commission. The drilling program designed to explore for new ore bodies at shallow depths and to test the extent of the exposed ore bodies was carried out by the U.S. Bureau of Mines during July and August 1952.

\section{GEOLOGY}

The Garo deposit is within the part of South Park that was geologically mapped and described by Stark and others (1949). The area is underlain by red beds of the Maroon formation of Pennsylvanian and Permian age and in part is covered by glacial and stream deposits of Quaternary age. Near Garo, the Maroon formation is several thousand feet thick (Stark and others, 1949, p. 44-45) and consists predominantly of siltstones, sandstones, and limestones. Within the mine area, these rocks are displaced along northwest- to northeasttrending high-angle faults as much as 1,000 feet horizontally (pl. 1).

The ore deposits are in three thick sandstone beds of the Maroon formation that dip steeply northeast. The known ore bodies appear to be lenticular, and their close association with faults suggests that the localization of the ore was controlled in part by faults. The ore bodies consist of uranium, vanadium, and copper minerals irregularly disseminated in the favorable parts of the sandstone beds. Channel samples across the ore bodies contain as much as 0.48 percent uranium, 1.37 percent $\mathrm{V}_{2} \mathrm{O}_{5}$, and 1.34 percent copper (table 1).

\section{ROCK UNITS}

The Maroon formation within the mapped area is composed of interbedded maroon to white sandstones, siltstones, and shales and 
light- to dark-gray limestones. Distribution of the mappable lithologic units is shown on plate 1 . The sandstones, siltstones, and shales are eroded into low valleys separated by low north-trending ridges of limestones.

The sandstones are fine grained to coarse grained, locally conglomeratic and highly micacoous. They occur in beds from 1 to 30 feet thick. Although crossbedding is well developed in some beds, parallel bedding is dominant. Three sandstone beds in the Maroon formation contain uranium, vanadium, and copper minerals, and they have been designated as sandstone beds 1,2 , and 3 .

Sandstone bed 1 is the youngest known ore-bearing lithologic unit and is exposed in pits 1 and 3 and in prospeot pits northwest of pit 3 (pl. 1). The bed averages 9 feet in thickness and is a marcon fine- to coarse-grained poorly sorted calcareous sandstone. In pit 1 , bed 1 is ore bearing and is a well-cemented white sandstone, but in pit 3 , it is dark brown to yellow green to green where ore minerals are abundant.

Sandstone bed 2 is stratigraphically 50 feet lower than bod 1 and is only exposed in the prospect pits southwest of pit 1 and west of pit 3 (pl. 1). It is 18 to 30 feet thick and is maroon medium- to coarsegrained micaceous sandstone that in the upper 3 to 5 feet is a white loasely cemented conglomeratic sandstone containing quartz and feldspar grains as much as one-sixteenth inch across. Yellow-green vanadium-uranium minerals are sparsely distributed in the white conglomeratic sandstone.

Sandstone bed 3 is stratigraphically 150 feet lower than bed 1 and is well exposed in pit 2 (pl. 1). Bed 3 averages 8 feet in thickness. It is a marcon to white fine- to medium-grained micaceous sandstone that in the lower 2 feet contain a thin lense of white conglomeratic sandstone. In pit 2 , bed 3 is a white to yellow-green friable sandstone that is ore bearing.

Shales, siltstones, coarse-grained arkosic sandstones, and fine- to medium-grained sandstones not known to be ore bearing make up the bulk of the Maroon formation in the mine area. The thin-bedded siltstones, shales, and sandstones range from less than 1 to 22 feet in thickness. They are generally calcareous and maroon to red except where bleached white gray adjacent to faults and fractures containing calcite or ore minerals. Individual shale and siltstone beds are lenticular and generally are not continuous along strike or downdip between drill holes. Some of the sandstone beds are persistent, and drill-hole data indicate that they are traceable throughout most of the mine area. The arkosic sandstones are exposed southeast of the mine, and have been cut by drill hole 2. These beds are marcon to 
bright red very coarse-grained calcareous massive rocks that contain. abundant coarse mica flakes.

Seven limestone beds were mapped in the mine area (pls. 1, 2). They range from 1 to 15 feet in thickness and are light- to dark-gray thin-bedded to massive fine-grained rocks that locally contain sandstone fragments and chert. A 2- to 7-foot limestone bed that is 3 to 15 feet stratigraphically above sandstone bed 3 contains abundant radioactive chert. The limestone is dark gray, fine grained, and is well exposed throughout the mapped area. The chert occurs as irregular masses in the limestone, and is blue, white, yellow, black, and red on fresh surfaces but is white gray on weathered surfaces. Five samples of variously colored cherts from this bed northwest of fault 2 contain 0.006 to 0.008 percent uranium (pl. 1), and the chemical uranium analyses are nearly the same as the measure of total radioactivity. The color of chert is apparently unrelated to radioactivity. According to G. B. Gott (1951, written communication), chert from this bed contains in addition to uranium as much as 0.05 percent $\mathrm{V}_{2} \mathrm{O}_{5}$ and 0.04 percent copper.

A chert-bearing limestone bed, 3 to 5 feet thick, was intersected by drill holes 10 and 12 at 20 to 30 feet below the surface, but the extent of this limestone bed is not known. The chert is abnormally radioactive.

\section{STRUCTURE}

The Garo deposit is on the northeast flank of the Garo anticline, one of several northwest-trending folds mapped by Stark and others (1949) in the northern part of South Park (fig. 2). The sedimentary rocks in the mapped area have a prevailing strike of N. $60-65^{\circ} \mathrm{W}$., $\operatorname{dip} 47^{\circ}-73^{\circ} \mathrm{NE}$., and are broken by a series of northwest- to northeast-trending high-angle normal and reverse faults (pl. 1). The attitude of the rocks near some of the faults deviates from regional trends.

Faults are the most easily recognized structural feature in the mine, and the more persistent of these have been numbered for reference purposes as faults $1,2,3,4$, and 5 . In the mine workings and drill cores, faults are marked by green-white gouge zones, 1 to 4 feet thick, that contain angular to rounded fragments of sedimentary rocks derived from the Maroon formation. In the area northwest of the mine workings, traces of the faults are generally covered by stream and glacial deposits, and the best criterion for the recognition of faults is the abrupt termination of the sandstone or limestone beds. Faults are also recognized locally, as in pits 1 and 3 and in several drill cores, by change in dip of the beds and by greenishwhite gouge. In addition to the faults shown on plate 1 , there are 


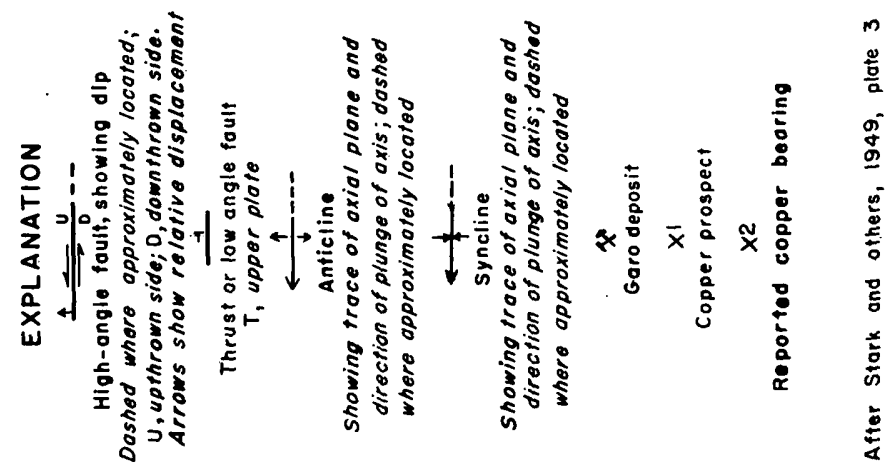

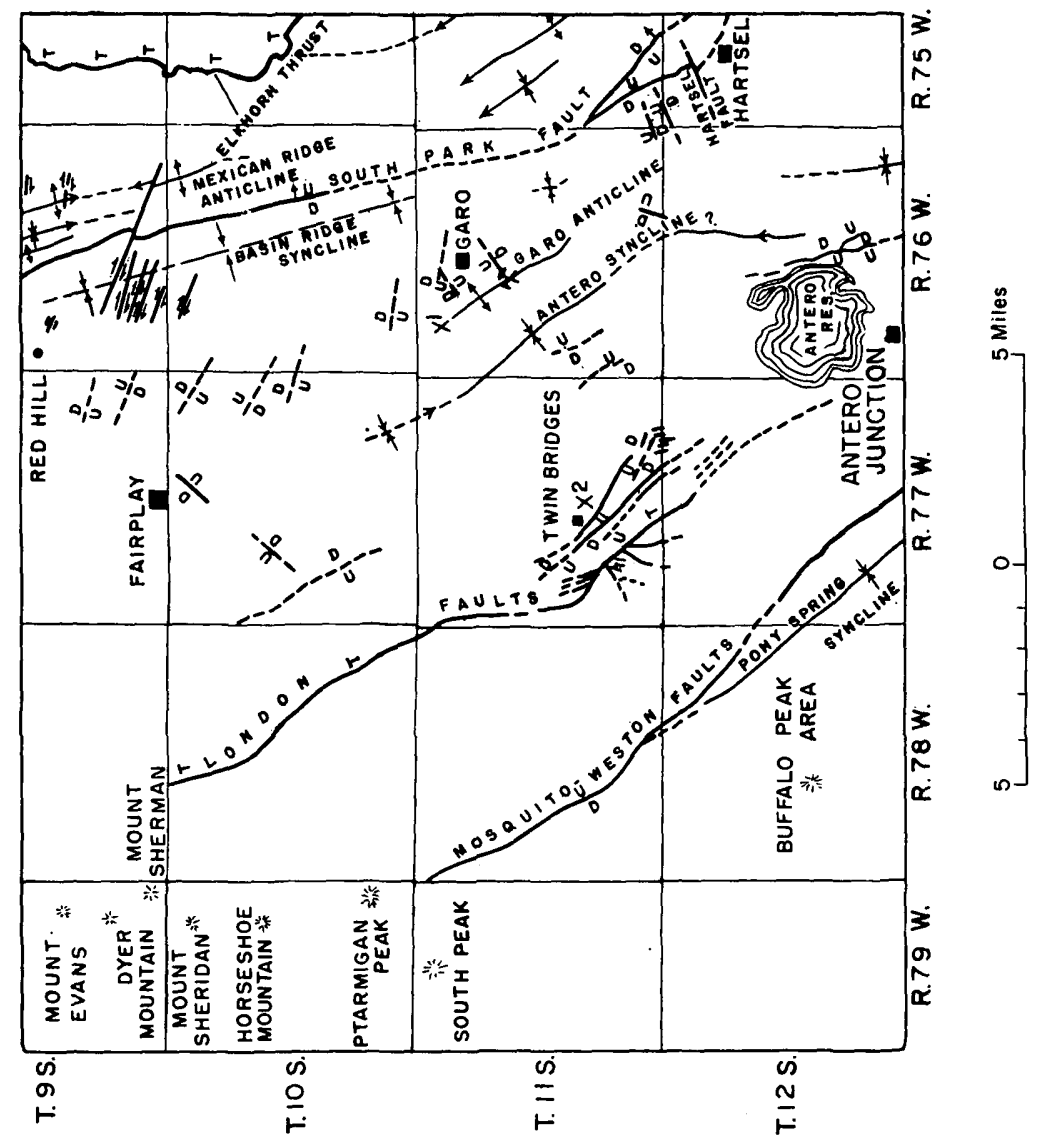


undoubtedly many more strike-slip faults that were not recognized because of their similarity in attitude of the faults and sedimentary rocks.

The five principal faults are transverse faults. They strike N. $10^{\circ} \mathrm{W}$. to $\mathrm{N} .35^{\circ} \mathrm{E}$.; and they dip as much as $88^{\circ} \mathrm{SE}$., as determined from surface and drill-hole data. The faults are normal and the apparent relative movement along all except fault 3 has been to move the west side of the fault northward. Fault 2, the largest fault, has displaced the beds possibly as much as 1,000 feet horizontally and 60 feet vertically. Many steeply dipping normal and reverse subsidiary faults have greatly complicated the structure between faults 2 and 5 . Most of these subsidiary faults trend northeast, but some trend northwest parallel to the attitude of the sedimentary rocks. They have horizontal displacements of from 5 to 50 feet and probably were formed contemporaneously with the larger and persistent faults. Most of the faults are generally believed to have formed before deposition of the ore and aided in localization of the uranium-vanadium-copper minerals.

A primary structural feature of the sedimentary rocks that may have been important in localizing the ore deposits is the apparent difference in attitude of the top and bottom of the ore-bearing sandstone beds. As shown in pits 3 and 2 (pl. 2), the dip of the hanging wall of the mineralized sandstone bed is $6^{\circ}$ to $10^{\circ}$ steeper than the footwall. Thus, down the dip of the bed, the ore-bearing sandstone would appear to pinch out; however, in drill hole 4, sandstone bed 1 is as thick as in pit 3, and sandstone bed 3 where cut by drill holes 7 and 8 is not decreased in thickness. Thus, the variation in dip across the uniformly textured sandstone bed is probably due to local thinning caused by scouring during sedimentation. The ore bodies in pits 2 and 3 appear to lie updip from such sedimentary structures.

Except for the small north-plunging fold with an amplitude of 3 feet exposed in pit 1, the rocks in the mine area were not extensively folded during formation of the faults. The effect of the minor folds on localization of the ore deposits is believed to have been slight.

\section{ORE DEPOSITS}

The ore at the Garo deposit is of the uranium-vanadium-copper sandstone type, though it differs from most ore of this type in that chalcocite and covellite and their alteration products are locally important constituents. Most of the ore was produced from sandstone bed 1 in pits 1 and 3 , but small quantities of ore were mined also from sandstone bed 3 in pit 2. There has been no production from sandstone bed 2 , but 3 potential ore deposits were discovered by diamond 
drilling in sandstone bed 2 between faults 3 and 4 . The principal ore minerals are tyuyamunite, metatyuyamunite, volborthite, chalcocite, and covellite; they occur as disseminated grains, as grain coatings, and as fracture fillings in the three sandstone beds.

Copper minerals are widely distributed throughout the mineralized sandstone beds, but only a few tons of copper ore has been produced, principally from sandstone bed 1 in pit 3 . The grade of the ore varies widely. Selected samples of dump material contain as much at 2.39 percent uranium and 4.34 percent $\mathrm{V}_{2} \mathrm{O}_{5}$, but channel samples across the mineralized sandstones contain from 0.001 to 0.48 percent uranium and from 0.05 to 1.37 percent $\mathrm{V}_{2} \mathrm{O}_{5}$. The copper content of selected ore samples is as much as 1.34 percent, but the average of channel samples from the ore-bearing sandstone is about $0.0 \mathrm{X}$ percent copper. Small quantities of silver, lead, titanium, and zinc are in the ores (table 1).

The ore produced from sandstone bed 1 was mined from pits 1 and 3 in the block of ground between faults 3 and 5. In pit 1, sandstone bed 1 was mined continuously along strike for about 120 feet and downdip for 30 feet. At the widest part, bed 1 was mined over a distance of about 30 feet, but the average mining width is about 7 feet. Channel samples of sandstone from pit 1 (pl. 2) contain from 0.001 to 0.035 percent uranium and from 0.09 to 0.19 percent $\mathrm{V}_{2} \mathrm{O}_{5}$ (table 1). Although none of these samples is of ore grade (containing more than 0.10 percent uranium), grab samples of ore from a stockpile, collected in 1946 by L. B. Riley, contained 0.32 percent $\mathrm{U}_{3} \mathrm{O}_{8}, 1.38$ percent $\mathrm{V}_{2} \mathrm{O}_{5}$, and 1.90 percent copper (L. B. Riley, 1946, written communication). The uranium content of samples obtained during mining operations in 1950 and 1951 is considerably higher than that shown by results of analyses of samples collected in 1952 (table 1), and indicates that the grade of the ore mined before 1952 is higher than the average of mineralized rock remaining in pit 1.

Sandstone bed 1 in pit 1 has been cut by 2 northwest-trending steeply dipping faults. This faulting may explain the absence of ore minerals in bed 1 where cut by drill holes 3 and 11 at depths of 65 and 42 feet downdip from the bottom of the pit (pl. 4). Samples of the core from bed 1 in these drill holes contain 0.002 percent equivalent uranium (pl. 4).

Sandstone bed 1 is not exposed between pits 1 and 3. A sample of core (GA-3A-53) from sandstone bed 1 where cut by drill hole 1 contains 0.002 percent equivalent uranium (pl. 4). These data suggest that sandstone bed 1 is not mineralized between fault 4 and pit 1 . In pit 3 , the mineralized sandstone has been mined from fault 4 northwestward along the strike for about 190 feet and downdip for 
about 15 feet. The extension of the ore body downdip is incompletely known; however, core samples (GA-17-53 and GA-30-53) from bed 1 where cut by drill holes 4 and 9 , at depths of 68 and 46 feet downdip from the bottom of the pit contain only 0.001 percent equivalent uranium (pl. 4). These data and convergence of the dips on the footwall and hanging wall of the sandstone bed (pl. 2) suggest that the ore-bearing part of sandstone pinches out a short distance downdip from bottom of the pit; however, the sandstone bed continues at depth and is 6 to 10 feet thick where cut by the drill holes (pl. 4). Twenty-six channel samples have been cut from bed 3 in pit 3 . Of these, only 4 samples contain more than 0.10 percent uranium; the remaining 22 samples contain from 0.001 to 0.096 percent uranium. The vanadium oxide content of all samples ranges from 0.05 to 1.37 percent and the copper content from 0.12 to 1.34 percent (table 1 ).

Sandstone bed 2 is not mineralized at the surface, but uranium, vanadium, and copper minerals were found in core from this bed where it was cut by diamond-drill holes 1,4 , and 5 (pl. 4). The top 4 to 5 feet of sandstone bed 2 in drill holes 4 and 5 is a white medium- to coarse-grained friable rock that contains tyuyamunite, volborthite, and malachite as disseminated grains and on fracture surfaces. Samples from these cores contain 0.003 to 0.018 percent uranium, 0.17 to 0.29 percent $\mathrm{V}_{2} \mathrm{O}_{5}$, and as much as 0.38 percent copper (table 1). In drill hole 1 , volborthite, tyuyamunite, and malachite coat the surface of a fracture, one-fourth inch wide, in the upper part of the bed, but the sandstone near the fracture was not mineralized. The extent of the mineralized sandstone cut in the drill holes is not known. Presumably the ore minerals occur in small lenses in the more permeable parts of the sandstone, similar to the occurrence of the ore mined from the surface excavations.

Uranium and vanadium minerals have been mined in sandstone bed 3 from the end of the underground workings (pl. 2) to the southeast end of pit 2. In August 1952, uranium- and vanadium-bearing sandstone formed a zone as much as 3 feet thick and 4 feet long on the hanging wall of the bed, at the east end of the pit. Where bed 3 is cut by diamond-drill holes 7 and 8 , no uranium, vanadium, or copper minerals were noted in the core and the bed was not abnormally radioactive. Samples of core (GA-27-53 and GA-29-53) contain 0.002 and 0.001 percent equivalent uranium (pl. 4, holes 7 and 8). The uranium and vanadium contents of samples (table 1 ) from pit 2 range from 0.001 to 0.062 percent uranium and from 0.05 to 0.49 percent $\mathrm{V}_{2} \mathrm{O}_{5}$. Sample GA-63 contains 0.16 percent copper. At the surface in the small pit about 100 feet northwest of pit 2, a channel sample (GA-67-53, table 1) across bed 3 contains 0.002 percent equivalent 


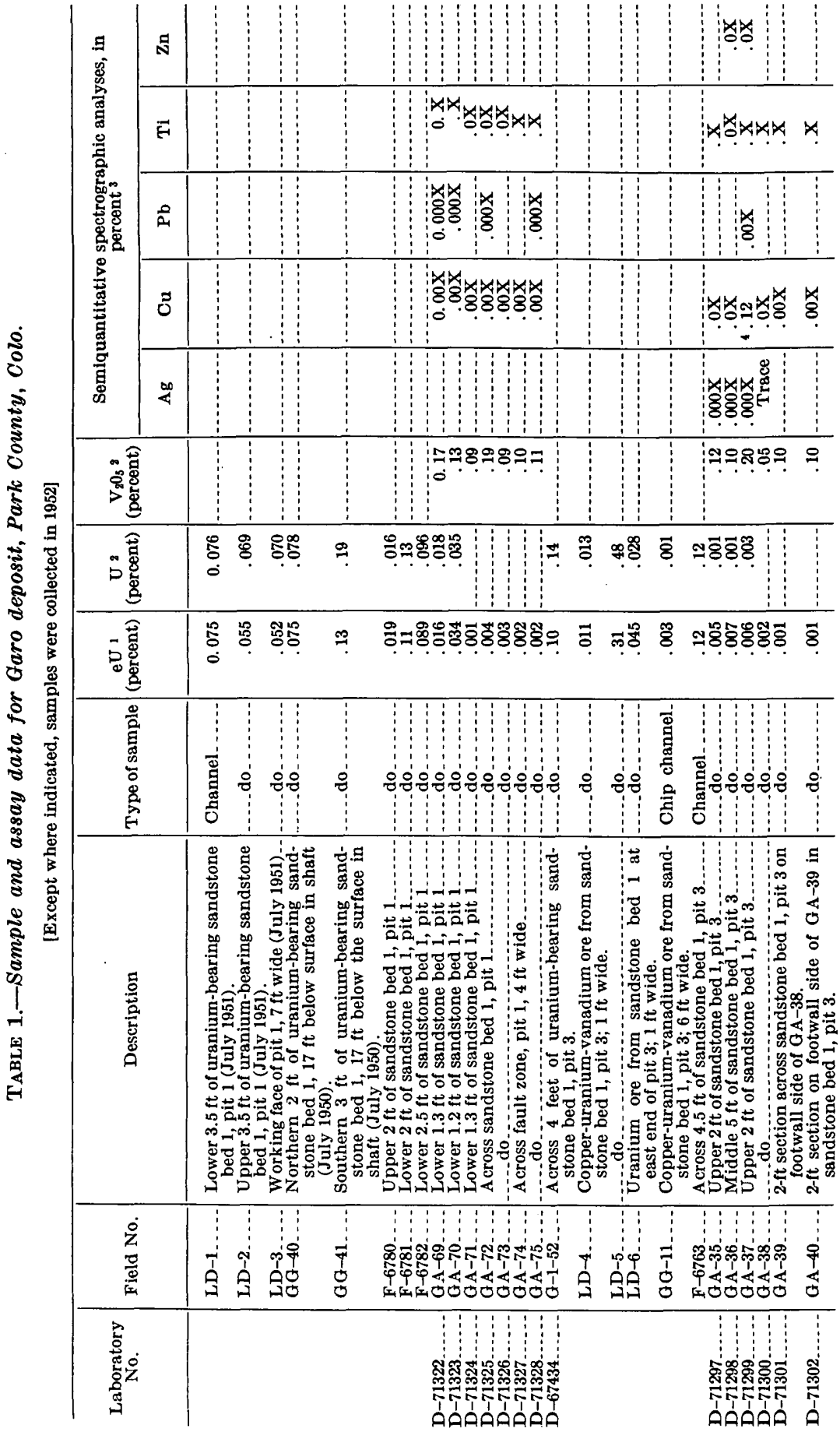




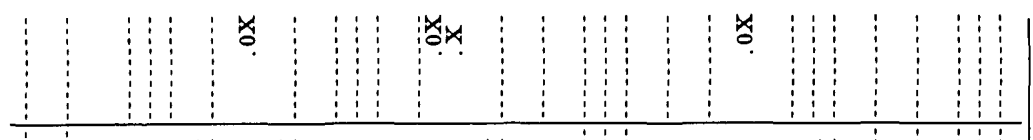

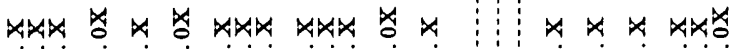

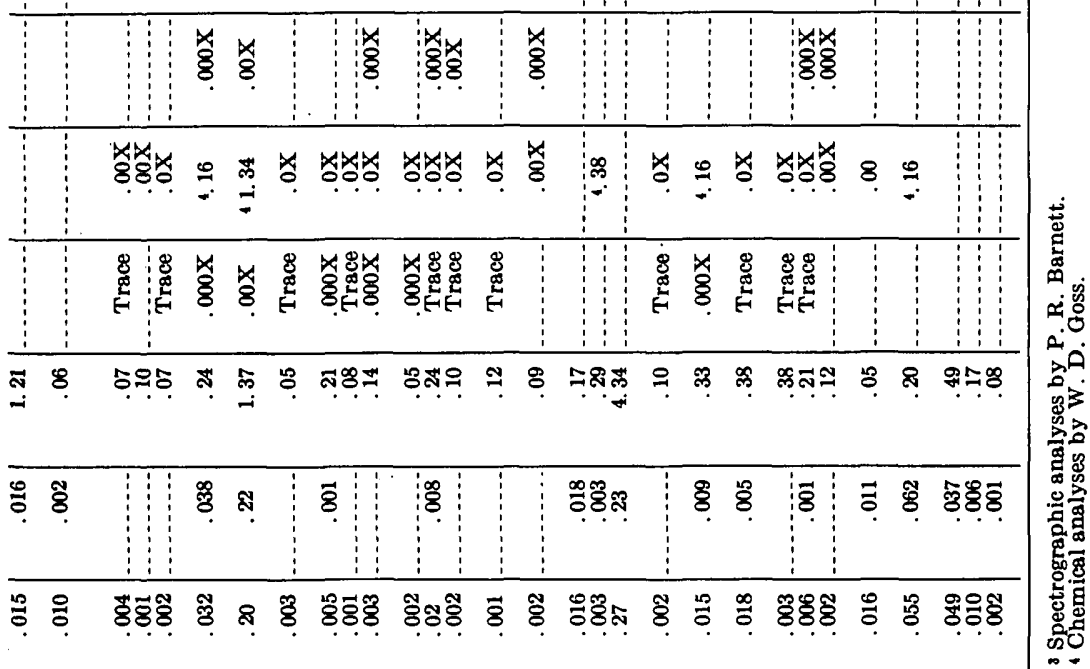

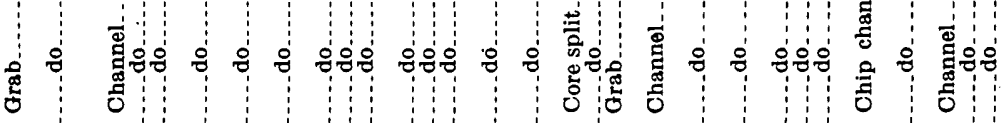

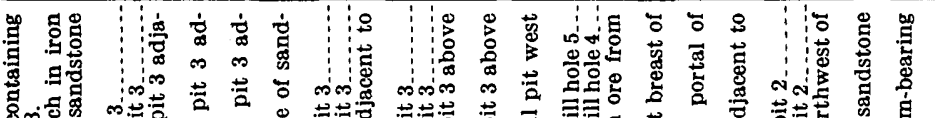

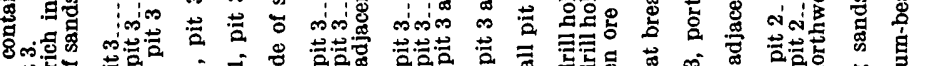

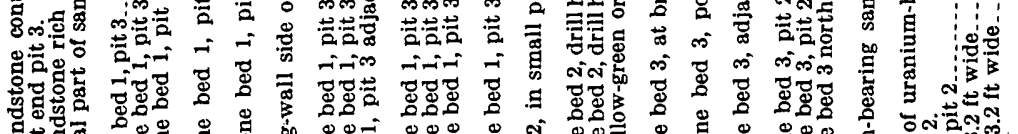

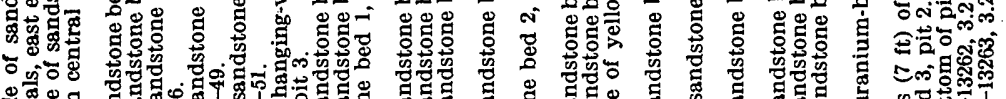

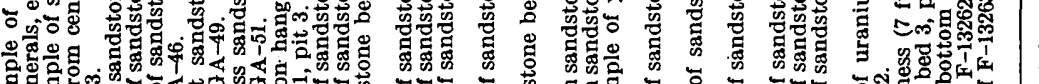

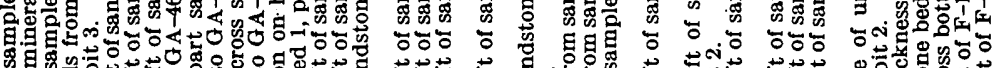

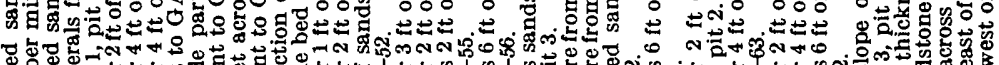

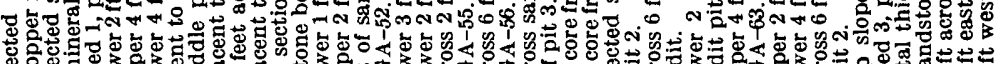

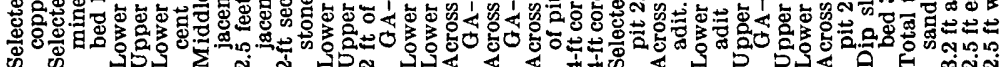

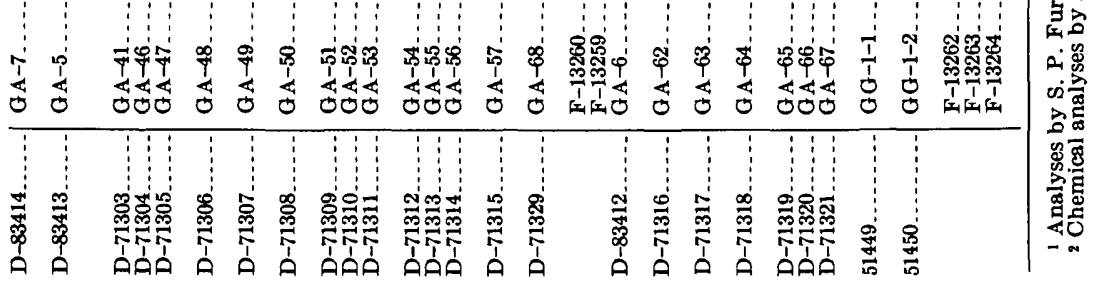


uranium and 0.12 percent $\mathrm{V}_{2} \mathrm{O}_{5}$; no uranium or vanadium minerals were visible. The mineralized part of the sandstone bed is apparently confined to the small area adjacent to a small fault exposed in the pit and appears to lens out within short distance downdip from the bottom of the pit and along the strike of the bed.

\section{LOCALIZATION OF ORE}

The mineralized zones of sandstone bed 2 and all the ore deposits that have been mined are between faults 3 and 5 . Specifically, the ore minerals appear to be localized in favorable parts of these sandstone beds where they are cut by subsidiary longitudinal faults (pls. 1,3 ). This relation is well shown in pit 3 (pl. 2) where the ore minerals were deposited only in sandstone that is adjacent to and cut by a subsidiary longitudinal fault. Similarly in pit 2, ore minerals have been found only in the highly fractured sandstone adjacent to a minor longitudinal fault. The mineralized part of sandstone bed 2, as indicated on plate 3 , seems to be unrelated to longitudinal faults; the structure, however, is incompletely known and minor faults may be present and may have aided in localizing the ore minerals.

The localization of ore minerals in certain parts of the sandstone beds is due largely to variations in permeability of the host rock. Features of the sandstone that directly affect permeability are composition, texture, and structure. Study of thin sections cut from mineralized and unmineralized sandstone has shown that the mineral composition of the detrital grains in both types of sandstone is similar. Some variation, however, was noted in the carbonate cementing material which, with but few exceptions, is generally more abundant and coarser grained in the ore-bearing sandstone. Therefore, the original composition of the sandstone was not an important factor in ore deposition.

In the mineralized sandstones, the grain size was an important factor in localizing the ore minerals. Almost everywhere, the coarser grained parts of the sandstones are mineralized in preference to the finer grained rocks. In those mineralized sandstones that are poorly sorted, the large grains usually were loci for deposition of the ore minerals. Drill hole data show that the conglomeratic upper part of sandstone bed 2 is known to contain ore minerals, whereas the fine-grained sandstone in the lower part of the bed is not mineralized.

A primary structural feature observed in the mineralized parts of sandstone beds 1 and 3 is steeper dips on the hanging wall than on the footwall of the bed (pl. 2). This would suggest that the bed would pinch out at depth, but drill-hole data indicate that the beds are continuous downdip. The local pinching and swelling of the ore- 
bearing sandstone, together with increased permeability from fractures developed during formation of the subsidiary faults, may have been important local factors that governed ore deposition.

\section{CHARACTER OF ORE}

Ore at the Garo deposit consists of sandstone impregnated with uranium, vanadium, and copper minerals. It was mined principally for uranium and vanadium but small quantities of copper ore were also produced. The yellow to yellow-green tyuyamunite, metatyuyamunite, volborthite, and carnotite are the most abundant uranium and vanadium minerals, but small quantities of uranophane and calciovolborthite are present locally. The copper ore minerals include chalcocite, covellite, malachite, and azurite. Gangue minerals in the ore are hematite, calcite, chalcedony, and pyrite; of these, calcite is the most abundant.

The ores from the three pits are similar mineralogically, but differ widely in their proportions of ore and and gangue minerals.

In pit 1 , the ore is characteristically white, and contains as much as 25 percent calcite as the cementing material in the sandstone. Tyuyamunite and metatyuyamunite are the common ore minerals; they occur as widely disseminated grains that replace the calcite cement and as fracture fillings. Most of the ore mined from pits 2 and 3 is yellow to yellow green and is generally friable and crudely banded. Tyuyamunite, metatyuyamunite, volborthite, and carnotite occur as grain coatings, as fissure fillings, as cementing material in the sandstone host rock, and as crystals and crystalline aggregates interstitial to the sand grains. Irregular bands and lenses parallel and subparallel to the bedding of the host rock are common in the ore and are formed by ore minerals filling interstices of the sandstone (pl. $5 A, B, E$ ). Hematite is locally abundant in the ore where it occurs along fractures and forms the cement in irregular areas in the sandstone. A selected sample ( $\mathrm{GA}-6)$ of the yellow-green ore from pit 2 contains as much as 0.23 percent uranium and 4.34 percent $\mathrm{V}_{2} \mathrm{O}_{5}$ (table 1).

In pit 3, copper and iron minerals are locally common constituents of the uranium-vanadium ore. The copper minerals chalcocite, covellite, azurite, and malachite were sufficiently abundant in the ore from the east end of pit 3 that small quantities of copper ore were recovered. Specimens of the copper ore show that the copper sulfides occur as narrow fissure veins and as grains disseminated throughout the ore $(\mathrm{pl} .5 F, G)$. Most of the chalcocite and covellite are altered to: malachite and azurite but chrysocolla is present in some ore. Some 
of the ore is banded and consists of a core of altered chalcocite and covellite successively, surrounded by rings of tyuyamunite, volborthite, and malachite ( $\mathrm{pl} .5 \mathrm{C}$ ). In other specimens, however, fractures containing tyuyamunite, metatyuyamunite, and volborthite cut areas in which disseminated grains of copper sulfides, are a part altered to malachite. The copper content of the ore ranges widely and is as high as 1.34 percent; the average grade is much less (table 1). A selected sample $(\mathrm{GA}-7)$ of copper-bearing sandstone from pit 3 contains 0.016 percent uranium and 1.21 percent $\mathrm{V}_{2} \mathrm{O}_{5}$ (table 1 ).

The uranium-vanadium ore from pit 3 , especially the central part of sandstone bed 1 , is red brown, well cemented, irregularly banded, and contains abundant hematite and limonite (pl. $5 D$ ). Ore minerals where observed occur as irregular masses of finely crystalline intergrowths of tyuyamunite, matatyuyamunite, and volborthite widely scattered in the ore. A sample (GA-5) of the sandstone rich in iron minerals contains 0.002 percent uranium and 0.56 percent $\mathrm{V}_{2} \mathrm{O}_{5}$ (table 1).

\section{MINERALOGY}

The opaque ore minerals chalcocite and covellite are closely associated with the following secondary uranium, vanadium, and copper minerals (named in approximate order of abundance): tyuyamunite metatyuyamunite, volborthite, carnotite, malachite, azurite, calciovolborthite, chrysocolla, and uranophane. The gangue minerals are calcite, hematite, pyrite, and chalcedony. The complex uraniumvanadium minerals were identified by $A$. B. King and A. J. Gude 3d, of the Geological Survey, using X-ray diffraction methods. Identification of the opaque minerals and pargenetic relations of the ore and gangue minerals were determined by microscopic study of 65 thin and polished sections of the ore.

Chalcocite and covellite are the primary copper ore minerals at the Garo deposit. The chalcocite masses are made up of light bluish-gray isotropic chalcocite and a light- to dark-blue chalcocite which is for the most part isotropic, but may show some faint pale bluish-pink anisotropism. There are all gradations from masses of light-gray chalcocite containing few, if any, lathlike crystals of blue chalcocite to lathlike crystals of light-gray chalcocite in blue chalcocite. The distinctly blue chalcocite may contain as much as 8 percent covellite at room temperature. According to Edwards (1947, p. 74-76), the temperature of formation of blue chalcocite is above $75^{\circ} \mathrm{C}$. Covellite, where observed in polished sections, occurs either as narrow regular plates within, or as rims around, the chalcocite masses.

The chalcocite and covellite are found in narrow fissure veins but more abundantly as disseminated masses in the sandstone where these 
minerals replace in part the calcite cement and some of the sand grains. The veins are found only in the highly fractured sandstone near faults where they range in thickness from a knife blade to as much as one-fourth inch wide. Within the veins, the chalcocite and covellite occur as relict irregular masses as much as $3 \mathrm{~mm}$ across and 1 to $2 \mathrm{~mm}$ wide in irregular veins composed of intermixed malachite, azurite, and secondary uranium-vanadium minerals. Some of the veins are banded; hematite and unreplaced minerals form the core. Malachite forms a narrow zone about the core with the next outer zone composed of hematite-cemented sandstone containing irregular patches and lenses of sandstone cemented by tyuyamunite, metatyuyamunite, and volborthite.

Locally, replacement of the rounded sand grains along the vein walls results in formation of what has been described by Bastin (1950, p. 42) as atoll structures. The cores of the replaced grains contain relict masses of chalcocite and covellite surrounded by secondary copper, uranium, and vanadium minerals. Hematite containing some tyuyamunite forms the outer rim of these structures. The degree of replacement of the sand grains decreases away from the vein until only sparse rounded masses of chalcocite and covellite occur between the sand grains.

The uranium and vanadium minerals which make up the ore at the Garo deposit include tyuyamunite, metatyuyamunite, carnotite, volborthite, calciovolborthite, and uranophane. Except for uranophane, these ore minerals are uranium-bearing vanadates.

Volborthite is a hydrous vanadate of copper, calcium, and barium that contains minor quantities of uranium. A selected sample of volborthite obtained from the ore in pit 2 contains by spectrographic analysis: XX.0 percent each of copper and vanadium, X.0 percent calcium, $0 . X$ percent each of barium and uranium, and a trace of lead. Although the optical data on the volborthite from this sample are incomplete, $n$ is greater than $1.932,2 \mathrm{~V}$ is moderately large, and the birefringence is moderate. Volborthite occurs as disseminated grains, as fracture fillings, and as crystalline aggregates on fracture surfaces in the sandstone. The disseminated volborthite is light to dark green in transmitted light and occurs as finely crystalline aggregates replacing the calcite cement. Veins as much as $2 \mathrm{~mm}$ wide, consisting dominantly of volborthite, fill fissures in sandstone cemented by volborthite and tyuyamunite and grade into veins consisting of tyuyamunite and malachite. Botryoidal masses of dark-green volborthite occur as coatings on fracture surfaces in sandstone; when these masses are broken, the volborthite is light green. Some of the volborthite coats hematite on fracture surfaces. 
- Minor quantities of light gray-green lustrous flakes, tentatively identified as calciovolborthite, are closely associated with the volborthite. The calciovolborthite appears to be more abundant in the dark red-brown ore from pit 3.

Tyuyamunite, metatyuyamunite, carnotite, and uranophane are the only uranium minerals known at the Garo deposit. Tyuyamunite, the hydrated calcium-uranium vanadate; metatyuyamunite, the dehydrated tyuyamunite; and carnotite, the potassium analogue of tyuyamunite, occur similarly to volborthite. These minerals are closely associated in the ores, and, though easily. identified by $\mathrm{X}$-ray analyses, they are finely crystalline and generally difficult to identify in thin sections.

Tyuyamunite and metatyuyamunite are most abundant and are irregularly distributed throughout the mineralized sandstone beds as a cementing material, as sparse crystals and crystalline aggregates filling interstices, as coatings on fracture surfaces, and in fissure veins. These ore minerals occur as finely divided crystalline mesh that has replaced the calcite cement in the sandstone and some of the sand grains, especially the altered feldspars. Rare crystals as much as $0.05 \mathrm{~mm}$ wide and $0.1 \mathrm{~mm}$ long are interstitial to the sand grains. In some of the coarse-grained mineralized sandstones coarsely crystalline tyuyamunite occurs as a rind on the larger sand grains. On the more open fractures botryoidal masses, as much as $3 \mathrm{~mm}$ across, of tyuyamunite and metatyuyamunite coat volborthite and hematite.

Tyuyamunite from the Garo deposit has been described by George (1949. p. 164) who gave the following properties: $\alpha=1.675, \beta=1.860$, $\gamma=1.885$, with $2 V 30^{\circ}-45^{\circ} ; Y=$ greenish yellow, $Z=$ deeper greenish yellow, and $X=$ colorless. The results of spectrographic analysis of three selected samples of tyuyamunite made by R. G. Havens, of the Geological Survey, are as follows: $\mathbf{X X}$ percent uranium; $\mathbf{X}$ to $\mathbf{X X}$ percent vanadium; X.0 percent each of calcium and silicon; $0 . X$ percent each of barium, aluminum, and strontium; and $0.0 \mathrm{X}$ percent copper and iron.

Carnotite and uranophane are present in only minor quantities in the ores. Presence of carnotite was determined by L. B. Riley (1946, written communication). It has not been identified positively by the writer, though probably some of the tyuyamunite and metatyuyamunite contain carnotite, especially in those sandstones containing altered feldspars. Uranophane, calcium-uranium silicate, was tentatively identified in thin sections of the ore from pit 3 where it occurs as finely crystalline radiated aggregates in the chalcedony-cemented sandstone. 
Malachite and azurite, the principal alteration products of chalcocite and covellite, fill interstices in the sandstone where they replace the calcite cement; near the copper-bearing veins, they replace some of the sand grains. Some narrow malachite veins cut the uraniumvanadium rich sandstone and represent redistribution of copper by surface waters. Azurite is rarely found in veins but is the cementing material in the sandstone.

Chrysocolla is a rare mineral in the ore, and occurs only as a replacement of chalcocite and covellite in the chalcedony-cemented sandstone from pit 3.

Calcite is the dominant cementing material in the mineralized, as well as the unmineralized, sandstone. It also occurs as veins along faults and joints in the mine area. The calcite cement in the unmineralized sandstone is finely crystalline, and contains abundant minute inclusions which gives the calcite a light-red color. No evidence was found to indicate replacement of the detrital grains by the calcite cement during lithification. In the mineralized sandstone, the calcite is coarse grained, commonly clear, and replaces in part some of the detrital grains. This calcite may have been introduced by the ore solutions but more likely was the result of solution of the original calcite cement and redeposition in the ore-bearing sandstones. The white- to light-gray vein calcite is coarse grained and usually forms subhedral crystals, whose long axes are normal to the vein walls. The red to maroon sandstones, siltstones, and shales adjacent to the calcite veins are bleached to a light gray. On more open fractures clear euhedral calcite crystals, as much as $4 \mathrm{~mm}$ long parallel to the fracture walls, are coated by crystals of tyuyamunite and volborthite.

Hematite and limonite are common constituents of the mineralized sandstone from pit 1 , occuring as interstitial fillings in the sandstone. As is shown on plate $5 D$, contacts between the reddish-brown limoniterich sandstone and dark-brown hematite-rich sandstones are sharp and highly irregular; in some places these sandstones are separated by unmineralized rock. Generally hematite-bearing sandstone surrounds the limonite-rich parts of the sandstone. In thin sections of rock specimens the hematite and limonite have almost wholly replaced the calcito cement and to a lesser extent the sand grains. Semiquantitative spectrographic analyses of selected samples of these sandstones (table 2 ) show that there is little variation in the content of the metals in the rocks. Small masses of subhedral pyrite, largely altered to hematite, are in some of the copper sulfide veins. The hematite is locally concentrated at intersections of veins, as well as along the vein walls intermixed with secondary uranium, vanadium, and copper minerals. In addition to the hematite closely associated with the ore minerals, 
authigenic hematite occurs as very small rounded masses in the calcite cement.

TABLE 2.-Semiquantitative spectrographic analysis, in percent

[Analyses by R. G. Havens, U.S. Geological Survey]

\begin{tabular}{|c|c|c|c|c|c|c|c|c|c|c|c|c|}
\hline & $\mathrm{Fe}$ & $\mathrm{Mn}$ & $\mathrm{Ca}$ & $\mathrm{Mg}$ & $\mathrm{Ag}$ & $\mathrm{Ba}$ & $\mathrm{Cu}$ & $\mathrm{Ga}$ & $\mathrm{Pb}$ & $\mathrm{V}$ & $\mathbf{Y}$ & $\mathrm{Zn}$ \\
\hline $\begin{array}{l}\text { Red-brown hem- } \\
\text { atite-bearing } \\
\text { sandstone-. } \\
\text { Dark-brown homa- } \\
\text { atite-bearing } \\
\text { sandstone... }\end{array}$ & $0 . \mathrm{X}$ & $\begin{array}{r}0.0 \mathrm{X} \\
.0 \mathrm{x}\end{array}$ & $\begin{array}{l}\mathbf{x} . \\
\mathbf{x} .\end{array}$ & $0 . x$ & $\left\{\begin{array}{l}0.000 \mathrm{X} \\
.000 \mathrm{x}\end{array}\right.$ & $\begin{array}{r}0.0 \mathrm{X} \\
.0 \mathrm{X}\end{array}$ & $\left\{\begin{array}{l}0.0 \mathrm{X} \\
.0 \mathrm{X}\end{array}\right.$ & Tr. & $\begin{array}{r}0.00 \mathrm{X} \\
.00 \mathrm{X}\end{array}$ & {$\left[\begin{array}{r}0.0 \mathrm{X} \\
.0 \mathrm{x}\end{array}\right.$} & $\begin{array}{r}0.00 \mathrm{X} \\
.00 \mathrm{X}\end{array}$ & $0.0 \mathrm{X}$ \\
\hline
\end{tabular}

Chalcedony, though not a common gangue mineral in the ore deposit, has replaced some of the calcite cement in the mineralized sandstone from pit 3.

A very fine grained light-gray clay mineral is locally abundant in the sandstones near the fissure veins. It has embayed and replaced some of the detrital grains.

\section{PaRAGENeSis}

The detrital grains which make up the mineralized sandstone at the Garo deposit were cemented by calcite before the orogenic movement which formed the faults and folds in the mine area. Following the faulting and folding, chalcocite, covellite, and minor pyrite were deposited in fractures and as disseminated grains in the sandstones adjacent to the faults. Paragenetic sequence of the sulfide minerals is largely obscured by secondary minerals, though it is believed that these minerals were deposited contemporaneously. The clay(?) mineral presumably was deposited contemporaneously with the vein minerals.

As seen in polished and thin sections of the ore, some of the hematite as rounded specks is closely associated with the calcite cement and is clearly syngenetic in origin. The hematite which rims and veins the sand grains and locally forms a large part of the vein material was presumably derived by the alteration of pyrite. In the sandstone interstices the hematite was formed before deposition of the secondary copper and uranium-vanadium minerals.

The chalcocite and covellite masses are almost everywhere veined and replaced by malachite, azurite, and locally chrysocolla. Although this relation is usually obscured in the veins, it is well shown where the chalcocite occurs as disseminated grains in the sandstones. The deposition of tyuyamunite, metatyuyamunite, carnotite, volborthite, and calciovolborthite followed the formation of secondary copper minerals. The paragenetic sequence of these minerals is difficult to 
determine and varies somewhat with the minerals present in the ore. In the more open fractures, botryoidal masses of volborthite are coated by crystals of tyuyamunite. Specimens of the copper-rich ore show, however, that the volborthite-bearing sandstone surrounds the tyuyamunite-rich areas and apparently was deposited later. In thin sections, the euhedral crystals of volborthite coat the sand grains, whereas tyuyamunite and metatyuyamunite fill the interstices between the sand grains and in part replace the volborthite; the reverse of this is also known. In the copper-rich ore where volborthite is apparently more abundant, it replaces the malachite; the volborthite in turn is veined and replaced by later tyuyamunite. Redistribution of some of the tyuyamunite and volborthite has occurred, as shown by these minerals occurring in narrow veins that not only transect chalcocite masses and adjacent areas of malachite but also tyuyamunite and volborthite-rich standstones. In general, deposition of the uranium and vanadium minerals was contemporaneous.

Small quantities of sericite as long narrow blades cut off tyuyamunite-bearing veins and transect grain boundaries between calcite cement and detrital grains. Sericite was the last mineral to have been formed.

\section{RESULTS OF ANALYSES}

Semiquantitative spectrographic analyses (table 1) of channel samples from the 3 pits, indicate that, except for lead, zinc, silver, copper, and titanium, the variation in minor metal content is small. The ores contain a trace of gallium; $0.000 \mathrm{X}$ to $0.00 \mathrm{X}$ percent of cobalt, nickel, vanadium, and yttrium; $0.00 \mathrm{X}$ to $0.0 \mathrm{X}$ percent of strontium, zirconium, and boron; $0.0 \mathrm{X}$ percent manganese; $0 . \mathrm{X}$ percent iron; X.0 percent of potassium, calcium, sodium, and aluminum ; and $\mathrm{XX}$ percent silicon. The barium content of the ores average $0.0 \mathrm{X}$ percent, though 1 sample (GA-49-52) containing $0 . \mathrm{X}$ percent is also rich in volborthite in which barium is known to replace some of the copper. The small quantity of zirconium in the ore is found in the zircons which are a minor accessory mineral in the sandstones of the Maroon formation.

The mode of occurrence of the lead, zinc, and titanium is not known because no discrete minerals in which these metals form a component part have been identified in the ore. The copper is undoubtedly contained in the many primary and secondary minerals found in the ores. Samples which have a copper content of greater than $0.00 \mathrm{X}$ percent commonly contain detectable quantities of silver, which suggests that silver is associated with the copper minerals. 


\section{SUGGESTIONS FOR PROSPECTING}

The outlook for new uranium-vanadium-copper deposits in the vicinity of the mine is difficult to evaluate. South and east of the mine glacial and stream deposits cover much of the bedrock, thus making prospecting by Geiger or scintillation counter extremely difficult or impossible. Examination of the rocks for several miles northwest of the mine revealed abnormal radioactivity only in the chertiferous limestone beds, though minor quantities of secondary copper minerals were found in prospect pits about 2 miles northwest of the mine. These results indicate that within the area examined the possibility of finding new deposits near the surface is unlikely.

Other areas in South Park, especially near Twin Bridges, that are geologically similar to the Garo deposit are shown on the map by Stark and others (1949, pl. 3) and may warrant investigation. Prospecting in these areas could best be carried out by radioactivity surveys by either ground or airborne equipment.

\section{LITERATURE CITED}

Bastin, E. J., 1950, Interpretation of ore textures : Geol. Soc. America Mem. 45, $101 \mathrm{p}$.

Edwards, A. B., 1947, Textures of the ore minerals and their signiflcance: Australasian Inst. Mining and Metallurgy, $185 \mathrm{p}$.

Fleck, Herman, 1909, The vanadium deposits at Garo, Park County, Colorado: Colorado School Mines Quart., v. 3, no. 3, p. 35-36.

George, D'Arcy, 1949, Mineralogy of uranium- and thorium-bearing minerals: U. S. Atomic Energy Comm. RMO-563, 198 p., issued by U. S. Atomic Energy Comm., Tech. Inf. Service, Oak Ridge, Tenn.

Stark, J. T., and others, 1949, Geology and origin of South Park, Colorado: Geol. Soc. America Mem. 33, 188 p. 


\section{N D E X}

\begin{tabular}{|c|c|}
\hline \multirow{2}{*}{$\begin{array}{c}\text { Page } \\
\text { Analyses of selected samples, semiquantita- } \\
\text { tive }\end{array}$} & Page \\
\hline & Minerals, deposition \\
\hline & Ore, grade \\
\hline ttitude of sedimentary rocks & $\begin{array}{r}\text { Ore minerals, localization } \\
\text { principal }\end{array}$ \\
\hline $\begin{array}{l}\text { hert, radioactive } \\
\text { opper minerals at Garo deposit } \ldots \ldots, 5,20 ; \text { pl. } 1 \\
13,14,15\end{array}$ & Pit 1 . \\
\hline evation of mine... & Pit $3 . \ldots .4,5,8,10-11,12-13,16,17,18 ;$ pl. 2 \\
\hline uults $\ldots . . .5,5-7,8,12 ;$ pls. $1,2,4$ & Purpose of report......... \\
\hline lds & Sandstone bed 1.... 4 \\
\hline angue minerals at Garo deposit $\ldots \ldots \ldots .13,17,18$ & ed $2 \ldots . . . . . . . .$. \\
\hline aro anticline & ed $3 \ldots \ldots \ldots$ \\
\hline ude, A. J., 3d, minerals identifled by ......... & $\begin{array}{l}\text { Sandstone beas of Maroon lormation.... } \\
\text { Shirley May mine (Garo deposit) }\end{array}$ \\
\hline $\begin{array}{l}\text { avens, } \dot{R} . \text { G., semiquantitative spectro- } \\
\text { graphic analyses by }\end{array}$ & Structures, atoll, replacement of minerals in.- \\
\hline istory of deposit. $\ldots \ldots \ldots \ldots$ & $\begin{array}{rr}\text { from Garo deposit, properties.. } & 3,20 \\
16\end{array}$ \\
\hline als identified by. & (5) \\
\hline ; pls. 1, 2 & specting. \\
\hline Location of deposit.... & Urar \\
\hline oppons of & Van \\
\hline Taroon formation. & Volborthite, principal ore mineral...... \\
\hline $2-3,4-5,8,9,13-18 ;$ pl. 5 & spectrographic analysis... \\
\hline
\end{tabular}

\section{1}

